University of Nebraska - Lincoln

DigitalCommons@University of Nebraska - Lincoln

Agronomy \& Horticulture -- Faculty Publications

Agronomy and Horticulture Department

3-1-1987

\title{
Yield Accumulation, Leaf Area Index, and Light Interception of Smooth Bromegrass
}

\author{
R. K. Engel \\ University of Nebraska-Lincoln \\ Lowell E. Moser \\ University of Nebraska-Lincoln, Imoser1@unl.edu \\ James L. Stubbendieck \\ University of Nebraska-Lincoln, jstubbendieck@unl.edu \\ S. R. Lowry \\ University of Nebraska-Lincoln
}

Follow this and additional works at: https://digitalcommons.unl.edu/agronomyfacpub

Part of the Plant Sciences Commons

Engel, R. K.; Moser, Lowell E.; Stubbendieck, James L.; and Lowry, S. R., "Yield Accumulation, Leaf Area Index, and Light Interception of Smooth Bromegrass" (1987). Agronomy \& Horticulture -- Faculty Publications. 83.

https://digitalcommons.unl.edu/agronomyfacpub/83

This Article is brought to you for free and open access by the Agronomy and Horticulture Department at DigitalCommons@University of Nebraska - Lincoln. It has been accepted for inclusion in Agronomy \& Horticulture -Faculty Publications by an authorized administrator of DigitalCommons@University of Nebraska - Lincoln. 


\title{
Yield Accumulation, Leaf Area Index, and Light Interception of Smooth Bromegrass ${ }^{1}$
}

\author{
R. K. Engel, L. E. Moser, J. Stubbendieck, and S. R. Lowry ${ }^{2}$
}

\begin{abstract}
Smooth bromegrass (Bromus inermis Leyss.) is a cool-season grass used extensively in the midwestern USA for spring and fall grazing. Smooth bromegrass has limited production in this region during the summer. This study was conducted to document the growth characteristics and yield accumulation of smooth bromegrass under various levels of $\mathbf{N}$ fertilizer. Live yield (dry matter yield of living herbage), leaf area index (LAI), light interception (LI), and crop growth rate (CGR) were determined on an established stand of 'Lincoln' smooth bromegrass grown on a Sharpsburg silty clay loam (fine, montmorillonitic, mesic Typic Argiudolls) in eastern Nebraska. Zero, medium, and high $\mathbf{N}$ levels were maintained at each growth period. Irrigated spring, summer, and fall growths of smooth bromegrass were sampled at 1- or 2-week intervals in 1981 and 1982 depending on growth rate. Live yield, LAI, and CGR were all highest in the spring. Live yield reached a maximum of $10.3 \mathrm{Mg} \mathrm{ha}^{-1}$, CGR reached a maximum of $190 \mathrm{~kg} \mathrm{ha}^{-1} \mathrm{day}^{-1}$, and LAI reached a maximum of 6.8, which intercepted up to $99 \%$ of the incoming photosynthetic photon flux density during the spring growth period. Summer values for maximum live yield, LAI, and LI were $3.2 \mathrm{Mg} \mathrm{ha}^{-1}, 4.1$, and $73 \%$, respectively. Maximum values of live yield, LAI, and LI for the fall growth period were $2.8 \mathrm{Mg} \mathrm{ha}^{-1}, 5.2$, and $97 \%$, respectively. Smooth bromegrass has different growth and canopy characteristics at different seasons of the year. Growth models should consider seasonal differences in canopy characteristics as well as environmental parameters.
\end{abstract}

Additional index words: Bromus inermis Leyss., Crop growth rate, Nitrogen fertilization, Forage yield.

CMooth bromegrass (Bromus inermis Leyss.) is a $\checkmark$ cool-season grass that was introduced to the USA from eastern Europe (Stubbendieck et al., 1982). It initiates growth in early spring and will regrow in the fall if moisture and nutrients are available. Ranchers

\footnotetext{
' Contribution from the Dep. of Agronomy, Univ. of Nebraska published with approval of the Director, Nebraska Agric. Res. Div. Journal Series Paper no. 7985, Received 22 Jan. 1986.

${ }^{2}$ Former graduate student, professors of agronomy, and associate professor of biometry, respectively, Dep. of Agronomy and Dep. of Biometrics and Information Systems Center, Univ. of Nebraska. Lincoln, NE 68583.
}

Published in Crop Sci. 27:316-321 (1987). of the western Corn Belt utilize smooth bromegrass for pasture when warm-season pastures are dormant.

Smooth bromegrass yields are increased by $\mathrm{N}$ fertilizer (Colville et al., 1963) and are affected by harvest management (Marten and Hovin, 1980; Paulsen and Smith, 1969). However, there has been little detailed work conducted on smooth bromegrass to describe the development of the plant canopy and light interception (LI) during the growing season.

Critical leaf area index (LAI) has been defined as the LAI required to intercept $95 \%$ of the incoming radiation (Brougham, 1958). Brougham (1958) suggested that the critical LAI would vary with different species and for the same species as the seasons changed. Sheehy and Cooper (1973) concluded that the crop growth rate (CGR) of six temperate forage grasses depended upon the canopy interception of light. Davies (1971) stated that CGR probably was at a maximum over a LAI range of 5 to 10 with perennial ryegrass (Lolium perenne L.).

Since smooth bromegrass develops a rather uniform canopy of reproductive tillers in spring growth and has limited growth during the summer, understanding canopy development in addition to forage quality changes would be important in establishing harvest schedules. When modeling smooth bromegrass growth with generalized plant growth models (Smith and Loewer, 1983), biologically sound input parameters are needed in order to accurately simulate growth.

The objective of this study was to determine the growth and canopy development of smooth bromegrass with various levels of N. Yield, CGR, LAI, and LI of spring, summer, and fall growths were measured to document the canopy development of smooth bromegrass.

\section{MATERIALS AND METHODS}

This research was conducted at the University of Nebraska Agricultural Research and Development Center near Mead, in eastern Nebraska on an established stand of 'Lincoln' 


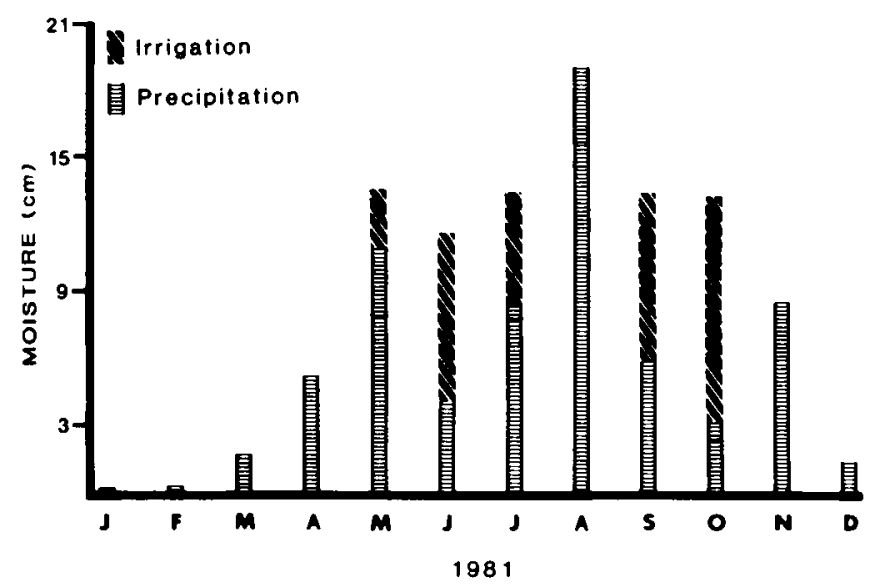

Fig. 1. Precipitation and irrigation received in 1981 by smooth bromegrass plots in this study.

smooth bromegrass. The stand was planted in 1974 on a Sharpsburg silty clay loam (fine, montmorillonitic mesic Typic Argiudolls) and hayed once or twice per year since 1975.

Three areas to be used for studying spring, summer, and fall growths were delineated. Within each area, representing a period of growth, three $\mathrm{N}$ fertilizer treatments (zero, medium, or high) were applied in strips. With the medium $\mathrm{N}$ treatment, $84 \mathrm{~kg} \mathrm{~N} \mathrm{ha}^{-1}$ as $\mathrm{NH}_{4} \mathrm{NO}_{3}(34-0-0)$ was applied by hand on 1 April to all plots. On 25 May, another $28 \mathrm{~kg}$ $\mathrm{N} \mathrm{ha}^{-1}$ was applied to the summer and fall growth plots and on 17 August another $56 \mathrm{~kg} \mathrm{~N} \mathrm{ha}^{-1}$ was applied to the fall growth plots. The high $\mathrm{N}$ plots received 168,56 , and $112 \mathrm{~kg}$ $\mathrm{N} \mathrm{ha}^{-1}$ at the above dates, respectively. The medium $\mathrm{N}$ plots received a season-long total of 84,112 , and $168 \mathrm{~kg} \mathrm{~N}^{-1}$ on the spring, summer, and fall growths, respectively. The high $\mathrm{N}$ plots received a total of 168,224 , and $336 \mathrm{~kg} \mathrm{~N}^{-1}$ on the spring, summer, and fall growths, respectively. The other treatment received no N. Clipping dates were replicated four times within the period of growth and $\mathrm{N}$ levels. Separate statistical analyses were conducted for each period of growth at each N level for 1981 and 1982. Prior to each growing period, all plots were cleared by mowing and hand raking. Natural precipitation was supplemented with sprinkler irrigation in both years so there was a minimum of 10 $\mathrm{cm}$ of moisture per month starting in late May 1981 and June 1982 (Fig. 1-2).

Two weeks after growth began in the spring or after spring or summer harvests, forage yield and leaf area were measured for each $\mathbf{N}$ treatment at 1-week intervals when the observed growth rate was rapid and at 2-week intervals when the growth rate was slow. Forage was harvested at each sampling date by clipping at ground level five random quadrats totalling $0.46 \mathrm{~m}^{2}$ within each subplot. Vegetation and current-year dead material were collected from each quadrat and composited to obtain one sample from each subplot. Samples were thoroughly mixed and a subsample of each was taken. These subsamples then were divided into green leaves (leaf blade removed at collar), green stems (collar attached), and dead material. Total leaf area of the subsample was determined with a Li-Cor LI-3000 area meter (Li-Cor, Lincoln, NE) ${ }^{3}$ and the samples were dried in a forced-air oven at $60^{\circ} \mathrm{C}$. Leaf area index, live yield (green stems, green leaves, and inflorescences), and CGR were determined.

\footnotetext{
${ }^{3}$ Trade and company names were included for the benefit of the reader and do not imply endorsement by the Nebraska Agric. Res. Div.
}

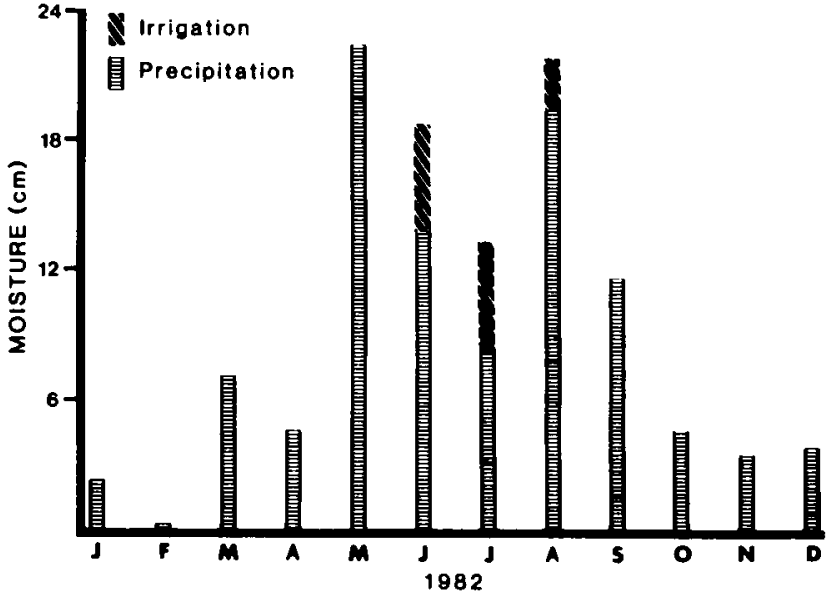

Fig. 2. Precipitation and irrigation received in 1982 by smooth bromegrass plots in this study.

Mean CGR was calculated for each harvest interval excluding the first and last 2 -week periods. The increase in live yield per hectare between harvest dates was divided by the number of days in the harvest interval to obtain kilograms per hectare per day. Light interception (LI) was measured in the fall of 1981 and during all three growth periods in 1982 , using a Li-Cor LI- $185 \mathrm{~B}^{3}$ light meter and line quantum sensor. Photosynthetic photon flux density $(400-700 \mathrm{~nm}$ ) was measured in micromoles per square meter per second. A light reading was first taken above the canopy to determine how much radiation was striking the canopy. Next, the line sensor was randomly placed on the ground in a north-south direction to determine how much light penetrated the vegetation. This was done three times immediately prior to each harvest for each subplot to be sampled near solar noon (1100 to $1300 \mathrm{~h}$ ) and the values were averaged. Percentage of light penetration of the canopy was determined by dividing the amount of light at ground level by the amount of light striking the canopy. Light interception was determined by subtraction of percentage of light penetration through the canopy from 100 .

Regressions for live yield on days after harvest, LAI on live yield, LI on live yield, and LI on LAI were conducted on each season of growth at each $\mathrm{N}$ level within each year. Linear and quadratic equations gave the best fit to the data. There was no advantage in using higher level polynomials. The natural log of LI was plotted against the natural $\log$ of LAI for the high and medium $\mathrm{N}$ levels for the spring 1982 comparison since this procedure was necessary to avoid a curve that peaked at an artificially high level (Steel and Torrie, 1980). Means and $95 \%$ confidence intervals were computed for maximum live yield, maximum LAI, and maximum LI for each growth period. Bonferroni's paired comparisons with a $5 \%$ level for the experimental error were used to compare mean live yield, LAI, and LI between years for each season at each $\mathrm{N}$ level (Snedecor and Cochran, 1980).

\section{RESULTS}

\section{Spring Growth Period}

Irrigation was not available for the first part of the spring of 1981 and the growth of smooth bromegrass was slowed due to water deficiency. There was ample moisture available in the spring of 1982 and bromegrass grew rapidly. Spring growth for 1982 has been illustrated to show the growth characteristics of spring growth of smooth bromegrass. Complete illustrations 
Table 1. Predictive equations from regression analyses for smooth bromegrass at three levels of $\mathbf{N}$ for three growth periods in 1981 and 1982.

\begin{tabular}{ll}
$\begin{array}{c}\text { Growth } \\
\text { period }\end{array}$ & N level \\
\hline & \\
Live yield $(y)$ vs. & time $(x)$ \\
Spring & 0 \\
Spring & Medium \\
Spring & High \\
Summer & 0 \\
Summer & Medium \\
Summer & High \\
Fall & 0 \\
Fall & Medium \\
Fall & High
\end{tabular}

No.
pairs

Error mean

Coefficient of square determination

LAI $\dagger(y)$ vs. live yield $(x)$

$\begin{array}{ll}\text { Spring } & 0 \\ \text { Spring } & \text { Medium } \\ \text { Spring } & \text { High } \\ \text { Summer } & 0 \\ \text { Summer } & \text { Medium } \\ \text { Summer } & \text { High } \\ \text { Fall } & 0 \\ \text { Fall } & \text { Medium } \\ \text { Fall } & \text { High }\end{array}$

LI $(y)$ vs. live yield $(x)$

$\begin{array}{ll}\text { Fall } & 0 \\ \text { Fall } & \text { Medium } \\ \text { Fall } & \text { High }\end{array}$

LI $(y)$ vs. LAI $(x)$

Fall

Fall

Fall

Medium

High

Live yield $(y)$ vs. time $(x)$

$\begin{array}{ll}\text { Spring } & 0 \\ \text { Spring } & \text { Medium } \\ \text { Spring } & \text { High } \\ \text { Summer } & 0 \\ \text { Summer } & \text { Medium } \\ \text { Summer } & \text { High } \\ \text { Fall } & 0 \\ \text { Fall } & \text { Medium } \\ \text { Fall } & \text { High }\end{array}$

LAI $(y)$ vs live yield $(x)$

$\begin{array}{ll}\text { Spring } & 0 \\ \text { Spring } & \text { Medium } \\ \text { Spring } & \text { High } \\ \text { Summer } & 0 \\ \text { Summer } & \text { Medium } \\ \text { Summer } & \text { High } \\ \text { Fall } & 0 \\ \text { Fall } & \text { Medium } \\ \text { Fall } & \text { High }\end{array}$

LI $(y)$ vs. live yield $(x)$

$\begin{array}{ll}\text { Spring } & 0 \\ \text { Spring } & \text { Medium } \\ \text { Spring } & \text { High } \\ \text { Summer } & 0 \\ \text { Summer } & \text { Medium } \\ \text { Summer } & \text { High } \\ \text { Fall } & 0 \\ \text { Fall } & \text { Medium } \\ \text { Fall } & \text { High }\end{array}$

LI $(y)$ vs. LAI $(x)$

$\begin{array}{ll}\text { Spring } & 0 \\ \text { Spring } & \text { Medium } \\ \text { Spring } & \text { High } \\ \text { Summer } & 0 \\ \text { Summer } & \text { Medium } \\ \text { Summer } & \text { High } \\ \text { Fall } & 0 \\ \text { Fall } & \text { Medium } \\ \text { Fall } & \text { High }\end{array}$

† Leaf area index.

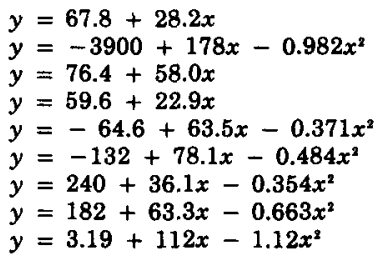

$\begin{array}{rr}0.02 & 0.86 \\ 0.48 & 0.23 \\ 0.56 & 0.28 \\ 0.02 & 0.98 \\ 0.13 & 0.94 \\ 0.25 & 0.92 \\ 0.06 & 0.84 \\ 0.17 & 0.88 \\ 0.45 & 0.87 \\ & \\ 119.9 & 0.71 \\ 123.2 & 0.82 \\ 13.7 & 0.98 \\ & \\ 131.6 & 0.68 \\ 153.4 & 0.77 \\ 18.5 & 0.98\end{array}$

1982

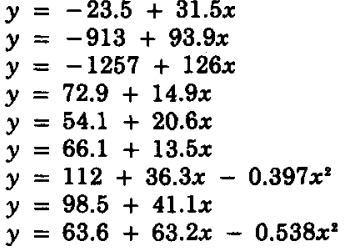

$\begin{array}{rl}76697 & 0.91 \\ 567795 & 0.93 \\ 1115314 & 0.92 \\ 45906 & 0.75 \\ 68771 & 0.80 \\ 95373 & 0.55 \\ 19156 & 0.86 \\ 11734 & 0.98 \\ 65462 & 0.89\end{array}$

$\begin{array}{ll}0.04 & 0.91 \\ 0.32 & 0.93 \\ 0.67 & 0.90 \\ 0.01 & 0.97 \\ 0.04 & 0.94 \\ 0.03 & 0.93 \\ 0.04 & 0.86 \\ 0.10 & 0.90 \\ 0.13 & 0.89\end{array}$

45.5

$\begin{array}{rr}45.5 & 0.83 \\ 0.042 \S & 0.96 \\ 0.029 \S & 0.96 \\ 155.8 & 0.80 \\ 105.0 & 0.87 \\ 67.6 & 0.88 \\ 50.8 & 0.84 \\ 46.0 & 0.93 \\ 181.8 & 0.73\end{array}$

$\begin{array}{rl}56.4 & 0.79 \\ 40.6 & 0.97 \\ 19.5 & 0.98 \\ 130.6 & 0.83 \\ 119.8 & 0.86 \\ 95.2 & 0.84 \\ 230.8 & 0.29 \\ 136.9 & 0.79 \\ 306.9 & 0.54\end{array}$


Table 2. Maximum live yield, maximum leaf area index, and maximum light interception for smooth bromegrass at three levels of $\mathbf{N}$ for three periods of growth in 1981 and 1982.

\begin{tabular}{|c|c|c|c|c|c|c|c|}
\hline \multirow[b]{2}{*}{ Season } & \multirow[b]{2}{*}{$\mathbf{N}$ level } & \multicolumn{2}{|c|}{ Maximum live yield } & \multicolumn{2}{|c|}{ Maximum leaf area index } & \multicolumn{2}{|c|}{ Maximum light interception } \\
\hline & & 1981 & 1982 & 1981 & 1982 & 1981 & 1982 \\
\hline & & -1 & & & & 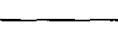 & \\
\hline $\begin{array}{l}\text { Spring } \\
\text { Spring } \\
\text { Spring }\end{array}$ & $\begin{array}{l}0 \\
\text { Medium } \\
\text { High }\end{array}$ & $\begin{array}{l}2.9(0.1) \dagger \\
4.5(0.5) \\
5.5(0.8)\end{array}$ & $\begin{array}{r}2.7(0.5) \\
7.2(1.4) \\
10.3(3.5)\end{array}$ & $\begin{array}{l}1.9(0.5) \\
3.9(0.6) \\
4.5(0.6)\end{array}$ & $\begin{array}{l}1.8(0.4) \\
5.2(1.4) \\
6.8(1.8)\end{array}$ & $\begin{array}{l}- \\
- \\
-\end{array}$ & $\begin{array}{l}57(3.7) \\
91(9.7) \\
99(1.8)\end{array}$ \\
\hline $\begin{array}{l}\text { Summer } \\
\text { Summer } \\
\text { Summer }\end{array}$ & $\begin{array}{l}0 \\
\text { Medium } \\
\text { High }\end{array}$ & $\begin{array}{l}2.1(0.3) \\
2.8(1.0) \\
3.2(0.7)\end{array}$ & $\begin{array}{l}1.2(0.3) \\
1.5(0.3) \\
1.1(0.9)\end{array}$ & $\begin{array}{l}2.6(0.3) \\
3.8(1.3) \\
4.1(0.4)\end{array}$ & $\begin{array}{l}1.6(0.3) \\
1.7(0.4) \\
1.3(0.9)\end{array}$ & $\begin{array}{l}- \\
- \\
-\end{array}$ & $\begin{array}{ll}73 & (4.8) \\
73 & (10.0) \\
61 & (20.2)\end{array}$ \\
\hline $\begin{array}{l}\text { Fall } \\
\text { Fall } \\
\text { Fall }\end{array}$ & $\begin{array}{l}0 \\
\text { Medium } \\
\text { High }\end{array}$ & $\begin{array}{l}1.2(0.4) \\
1.9(0.3) \\
2.8(0.3)\end{array}$ & $\begin{array}{l}0.9(0.2) \\
2.3(0.2) \\
1.9(0.3)\end{array}$ & $\begin{array}{l}2.0(0.2) \\
3.3(0.7) \\
5.2(0.6)\end{array}$ & $\begin{array}{l}1.4(0.2) \\
2.9(0.6) \\
2.8(0.5)\end{array}$ & $\begin{array}{l}70(4.0) \\
87(2.6) \\
98(0)\end{array}$ & $\begin{array}{l}77(2.3) \\
97(1.5) \\
97(3.5)\end{array}$ \\
\hline
\end{tabular}

$\dagger$ Figures in parentheses are $95 \%$ confidence intervals.

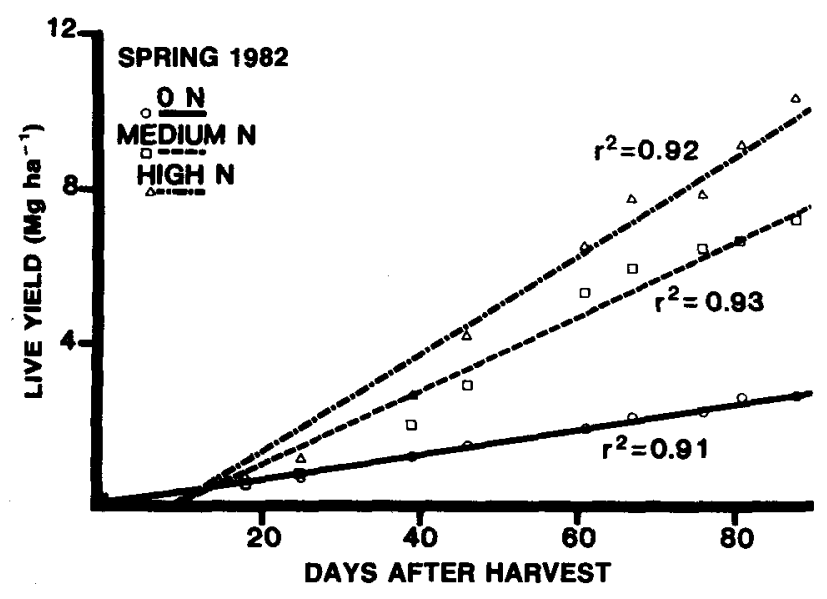

Fig. 3. Regression analyses of live yield on days after harvest (initial harvest, 1 April) for smooth bromegrass with three rates of $\mathbf{N}$ in the spring of 1982 .

for all growth periods can be found in Engel (1983). Predictive equations for all regression analyses are reported in Table 1. During the spring of 1982, smooth bromegrass accumulated live yield linearly for all $\mathrm{N}$ rates during the measurement period (Fig. 3). In the spring of 1982 maximum live yield of $10.3 \mathrm{Mg} \mathrm{ha}^{-1}$ was reached by plants fertilized with the high rate of $\mathrm{N}$ (Table 2). The dry conditions in the spring of 1981 as compared to 1982 resulted in a maximum live yield of only $5.5 \mathrm{Mg} \mathrm{ha}{ }^{-1}$ in the spring of 1981 . Live yields were significantly higher in 1982 than in 1981 for treatments that received $\mathrm{N}$.

In the spring of 1982, smooth bromegrass accumulated LAI in a linear fashion for unfertilized plants and those fertilized with the medium $\mathrm{N}$ rate, while plants with high $\mathbf{N}$ exhibited a quadratic increase in LAI (Fig. 4). A maximum LAI of 6.8 was reached by those plants receiving the highest $\mathrm{N}$ rate in 1982 (Table 2). Due to the drier conditions in the spring of 1981 a maximum LAI of only 4.5 was reached. Smooth bromegrass receiving $\mathrm{N}$ intercepted a maximum of $99 \%$ of the incoming radiation in the spring of 1982 with the high $\mathbf{N}$ rate (Table 2 ).

Critical LAI was defined as the LAI required to intercept $95 \%$ of the incoming light at solar noon and CGR does not decline with higher LAI values (Brougham, 1958). Optimum LAI was defined as the LAI at which the CGR is maximum but declines with

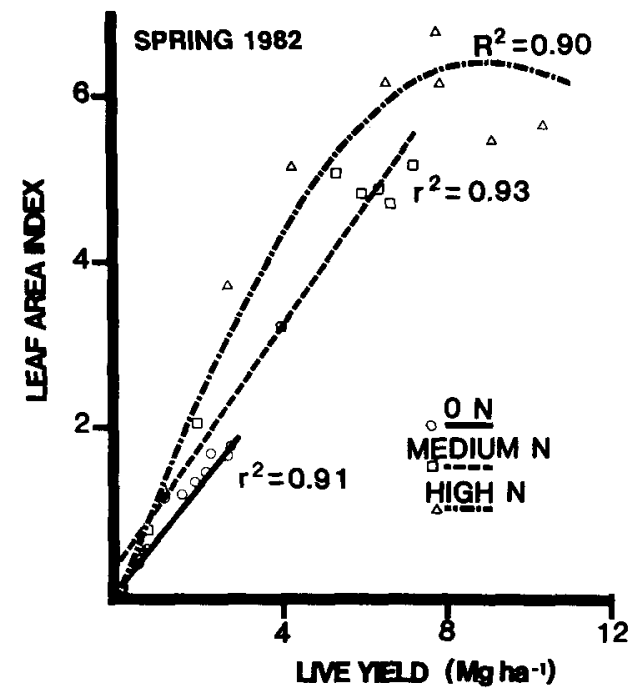

Fig. 4. Regression analyses of leaf area index on live yield for smooth bromegrass with three rates of $\mathrm{N}$ in the spring of 1982.

higher LAI (Davies, 1971). Use of the quadratic equation to predict LI from live yield for spring 1982 posed a problem. For both the medium and high $\mathrm{N}$ treatments, LI increased to near maximum at approximately $4 \mathrm{Mg} \mathrm{ha}^{-1}$ of live yield and then remained nearly constant up to maximum live yield of over 7 $\mathrm{Mg} \mathrm{ha}{ }^{-1}$ for the medium $\mathrm{N}$ level and up to over 10 $\mathrm{Mg} \mathrm{ha}^{-1}$ for the high $\mathrm{N}$ level (Fig. 5). Since a quadratic fit cannot make a sharp change in direction, the quadratic equation predicted $L I$ in excess of $100 \%$ for the high $\mathrm{N}$ treatment. Although linear plateau analysis using intersecting straight lines (Draper and Smith, 1981; Anderson and Nelson, 1975) provided a good fit, natural logarithmic transformations of both LI and live yield (Steel and Torrie, 1980) provided a single basic predictive equation with excellent fit. Plants without $\mathrm{N}$ fertilizer intercepted light in a linear manner (data not illustrated). They peaked at about $60 \% \mathrm{LI}$ at about $3.5 \mathrm{Mg} \mathrm{ha}^{-1}$ live yield (Table 1). Fertilized smooth bromegrass intercepted 90 to $99 \%$ of the incoming radiation at LAI values of 5 to 7 (Fig. 6). Plants receiving $\mathrm{N}$ reached a critical LAI ( $95 \%$ light interception) of 5.0 to 5.5 by about June 1. Maximum CGR values were highly variable. The highest CGR with a $90 \%$ confidence interval occurred with the spring growth in $1982\left(190 \pm 51 \mathrm{~kg} \mathrm{ha}^{-1}\right)$. The CGR values for the 


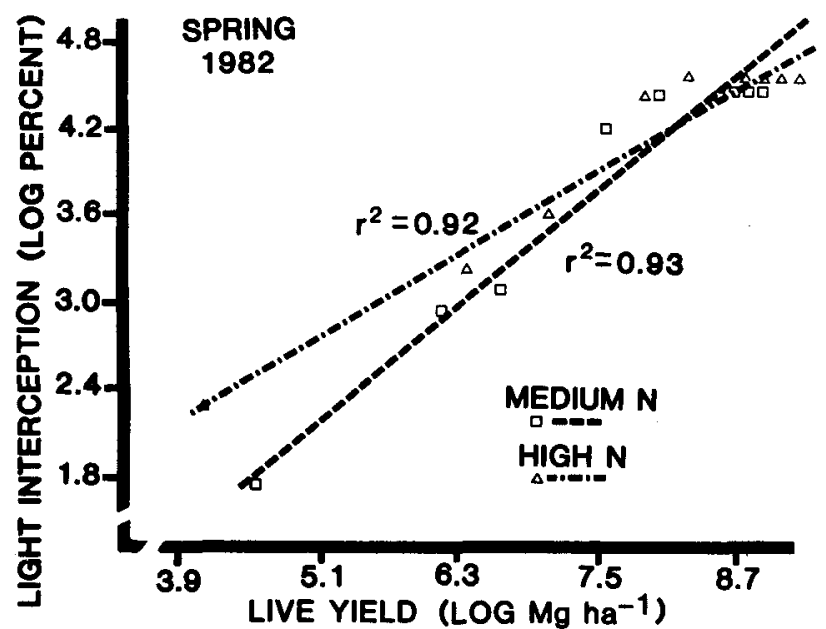

Fig. 5. Regression analyses of light interception on live yield for smooth bromegrass with three rates of $\mathrm{N}$ in the spring of 1982.y $=\log$ (light interception), $x=\log$ (live yield).

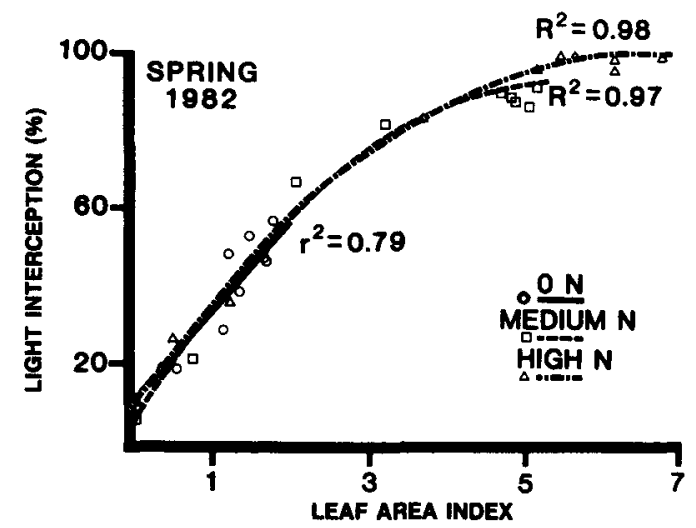

Fig. 6. Regression analyses of light interception on leaf area index for smooth bromegrass with three rates of $\mathrm{N}$ in the spring of 1982.

summer and fall growths were much smaller and highly variable.

\section{Summer Growth Period}

Due to heavy rainfall, waterlogged conditions occurred for several brief periods in June, July, and August of 1982. These waterlogged conditions caused reductions of maximum live yields in 1982 compared to 1981 (Table 2). Summer live yield accumulation at the medium and high $\mathrm{N}$ levels showed a quadratic response in 1981 and a linear response in 1982 (Table 1). During the summers of 1981 and 1982, smooth bromegrass exhibited a linear increase in LAI with increasing live yield for all rates of $N$ (Table 1). A maximum LAI of 4.1 was reached in the summer of 1981 compared to a maximum LAI of about 1.7 for 1982 (Table 2). The reduced stands of smooth bromegrass only intercepted about 60 to $70 \%$ of the incoming radiation at LAI values of about 1.3 to 1.7 (Table 2 ), so a critical LAI was not reached in the summer of 1982. The 1981 predictive equations describe the normal summer canopy development better than those in 1982.

\section{Fall Growth Period}

In the fall of 1981, smooth bromegrass exhibited a quadratic response for accumulation of live yield over days after harvest for each rate of $\mathrm{N}$ (Table 1). Waterlogged conditions in 1982 resulted in lower maximum live yields in the fall, compared to fall growth of 1981. Fall growths of smooth bromegrass accumulated maximum live yields of only 2.8 and $2.3 \mathrm{Mg}$ $\mathrm{ha}^{-1}$ in 1981 and 1982, respectively (Table 2). Plants fertilized with $\mathrm{N}$ reached a maximum LAI of 5.2 in the fall of 1981 , while in 1982 they only reached a maximum LAI of 2.9. Larger LAI values in the fall of 1981 over those in the fall of 1982 could be attributed to the different growth conditions of the $2 \mathrm{yr}$. Stands of smooth bromegrass recovering from waterlogged conditions in 1982 were shorter and denser than stands in the fall of 1981 . In the fall of 1981 , about $98 \%$ of the incoming radiation was intercepted at a LAI of about 4 (Table 2) in mid-September. In the fall of 1982, 95\% LI was reached at a LAI of about 2.5 in late September.

\section{DISCUSSION}

Seasonal differences in yield, LAI, LI, and CGR have been described by Brougham (1958), Woledge and Leafe (1976), and Parsons and Robson (1981). In our study, reproductive growth in the spring had elongated tillers, which provided for an erect, open canopy. This resulted in a higher maximum yield in the spring than for the subsequent vegetative regrowth. The erect spring growth produced a canopy that requires a higher LAI to intercept the same amount of incoming radiation as the short, dense canopies of vegetative growth.

Maximum live yields for both years were $10.3 \mathrm{Mg}$ $\mathrm{ha}^{-1}$ in the spring, $3.2 \mathrm{Mg} \mathrm{ha}^{-1}$ in the summer, and $2.8 \mathrm{Mg} \mathrm{ha}^{-1}$ in the fall with high $\mathrm{N}$. Critical LAI was about 5.0 in the spring of 1982 . Light interception values were not available for the summer of 1981 . However, the summer vegetative growth was similar to that in the fall of 1981 . In the fall of 1981 , a critical LAI of about 4 was reached. In the fall of 1982, a critical LAI of about 2.5 was reached. This lower, critical LAI could be attributed to the different growth characteristics of stands in 1982. Recovering stands in the fall of 1982 were shorter and denser than smooth bromegrass stands in the fall of 1981 . A critical LAI may have been reached in the summer of 1981, since LAI values of 4.1 were obtained at the high $\mathrm{N}$ level. This growth form also was very similar to that of the stands in the fall of 1982 .

Rhodes $(1969,1971 \mathrm{a}, \mathrm{b})$ stated that the difference between the CGR of vegetative and reproductive growths occurred because newly expanding leaves with elongating stems of reproductive growth developed in high light intensities. Woledge $(1977,1978,1979)$ indicated that leaves expanding in higher light intensities were more photosynthetically active than newly expanded leaves shaded by vegetative growth. This allowed the potential CGR to be larger in the spring reproductive growth than in the subsequent summer and fall vegetative growths. In addition, growth of a cool-season plant like smooth bromegrass would be restricted during hot summer weather. The late fall growth would be slowed by declining temperature and photoperiod. In our study, reproductive growth of smooth bromegrass in the spring of 1982 produced a maximum CGR of $190 \mathrm{~kg} \mathrm{ha}^{-1}$ day $^{-1}$, while vegetative 
regrowth in the summer and fall had a much smaller CGR.

Relating yield to live yield, LAI, and LI should be useful in understanding canopy development and yield accumulation of smooth bromegrass in the eastern Great Plains and western Corn Belt. With the difference in canopy structure between reproductive and vegetative growth, appropriate parameters must be used within the period of growth (spring, summer, and fall) to predict smooth bromegrass yield since they vary among the periods of growth. Level of $\mathrm{N}$ is an extremely important factor affecting growth, canopy development, and LI.

\section{REFERENCES}

Anderson, R.L., and L.A. Nelson. 1975. A family of models involving intersecting straight lines and concomitant experimental designs useful in evaluating response to fertilizer nutrients. Biometrics 31:303-318.

Brougham, R.W. 1958. Interception of light by the foliage of pure and mixed stands of pasture plants. Aust. J. Agric. Res. 9:39-52.

Colville, W.L., L. Chesnin, and D.P. McGill. 1963. Effect of precipitation and long term nitrogen fertilization on nitrogen uptake, crude protein content and yield of bromegrass forage. Agron. J. 55:215-218.

Davies, A. 1971. Changes in growth rate and morphology of perennial ryegrass swards at high and low nitrogen levels. J. Agric. Sci. $77: 123-134$.

Draper, N.R., and H. Smith. 1981. Applied regression analysis. 2nd ed. John Wiley and Sons, New York.

Engel, R.K. 1983. Leaf area index, light interception, and growth of smooth brome. M.S. thesis. Univ. of Nebraska-Lincoln.

Marten, G.C., and A.W. Hovin. 1980. Harvest schedule, persistence, yield, and quality interactions among four perennial grasses. Agron. J. 72:378-387.
Parsons, A.J., and M.J. Robson. 1981. Seasonal changes in the physiology of S24 perennial ryegrass (Lolium perenne L.). 2. Potential leaf and canopy photosynthesis during the transition from vegetative to reproductive growth. Ann. Bot. (London) 47:249-258.

Paulsen, G.M., and D. Smith. 1969. Organic reserves, axillary bud activity, and herbage yield of smooth bromegrass as influenced by time of cutting, nitrogen fertilization and shading. Crop Sci. 9:529-534.

Rhodes, I. 1969. The yield, canopy structure, and light interception of two ryegrass varieties in mixed culture and monoculture. J. Br. Grassl. Soc. 24:123-127.

---. 1971a. Productivity and canopy structure of two contrasting varieties of perennial ryegrass (Lolium perenne L.) grown in a controlled environment. J. Br. Grassl. Soc. 26:9-15.

--. 1971b. The relationship between productivity and some components of canopy structure in ryegrass (Lolium spp.). II. Yield, canopy structure, and light interception. J. Agric. Sci. 77:283-292.

Sheehy, J.E., and J.P. Cooper. 1973. Light interception, photosynthetic activity, and crop growth rate in canopies of six temperate forage grasses. J. Appl. Ecol. 10:239-250.

Smith, E.M., and O.J. Loewer, Jr. 1983. Mathematical logic to simulate the growth of two perennial grasses. Trans. ASAE 26:878883.

Snedecor, G.W., and W.R. Cochran. 1980. Statistical methods. 7th ed. Iowa State University Press, Ames.

Steel, R.G.D., and J.H. Torrie. 1980. Principles and procedures in statistics. 2nd ed. McGraw-Hill, New York.

Stubbendieck, J., S.L. Hatch, and K.J. Kjar. 1982. North American range plants. 2nd ed. University of Nebraska Press, Lincoln.

Woledge, J. 1977. The effects of shading and cutting treatments on the photosynthetic rate of ryegrass leaves. Ann. Bot. (London) 41:1279-1286.

--. 1978. The effect of shading during vegetative and reproductive growth on the photosynthetic capacity of leaves in a grass sward. Ann. Bot. (London) 42:1085-1089.

- 1 1979. Effect of flowering on the photosynthetic capacity of ryegrass leaves grown with and without natural shading. Ann. Bot. (London) 44:197-207.

--, and E.L. Leafe. 1976. Single leaf and canopy photosynthesis in a ryegrass sward. Ann. Bot. (London) 40:773-783. 